\title{
HABITAT REQUIREMENTS AND SELECTION BY KELP GULLS (LARUS DOMINICANUS) IN CENTRAL AND NORTHERN PATAGONIA, ARGENTINA
}

\author{
Pablo García Borboroglu ${ }^{1,3}$ and Pablo Yorio ${ }^{1,2}$ \\ ${ }^{1}$ Centro Nacional Patagónico, (CONICET), Boulevard Brown s/n, (9120) Puerto Madryn, Chubut, Argentina; and \\ ${ }^{2}$ Wildlife Conservation Society, 2300 Southern Boulevard, Bronx, New York 10460, USA
}

\begin{abstract}
Aвstract. - We analyzed habitat requirements and selection of Kelp Gulls (Larus dominica$n u s$ ) breeding at 68 colonies along 2,500 km of coastline in Patagonia, Argentina. Kelp Gulls use a wide range of nesting habitats that include areas with shrub, grass, and herbs which provide different degrees of cover; open ground of various substrate types; and slopes of widely different gradients, confirming the plasticity of the species with respect to habitat recorded elsewhere in the Southern Hemisphere. Eighty percent of the colonies were on islands, the probability of occupation of which increased with distance from mainland and availability of vegetation. Vegetation cover was a key component of nesting habitat for Kelp Gulls in Argentina. Gulls occupied areas with higher cover than random areas; but within vegetated areas, they showed preference for sparser cover that increased visibility and facilitated escape. Kelp Gulls often nested with other species of seabirds and seals and had a positive association with the Olrog's Gull (L. atlanticus). Received 22 October 2002, accepted 3 November 2003.
\end{abstract}

Resumen.-Analizamos los requerimientos y la selección de hábitat de gaviotas cocineras (Larus dominicanus) que reproducen en 68 colonias a lo largo de 2,500 km de costa en Patagonia, Argentina. La gaviota cocinera utiliza una amplia variedad de ambientes de nidificación que incluyen áreas con arbustos, pastos y hierbas que proporcionan diferentes grados de cobertura; sustratos de diferente composición y pendiente. Esto confirma la gran plasticidad en cuanto a la selección de hábitat observada en otras regiones del Hemisferio Sur. El 80\% de las colonias estuvieron ubicadas en islas, cuya probabilidad de ocupación aumentó con la distancia al continente y la disponibilidad de vegetación. La cobertura de la vegetación representó un componente clave del hábitat de nidificación para la gaviota cocinera en Argentina. Las gaviotas ocuparon áreas con mayor cobertura que las áreas elegidas al azar, sin embargo, dentro de las áreas con vegetación, mostraron preferencia por coberturas intermedias que incrementan la visibilidad y facilitan el escape. La gaviota cocinera nidificó frecuentemente con otras especies de aves marinas y lobos marinos, y presentó una asociación positiva con la Gaviota de Olrog (Larus atlanticus).

Habitat Selection is a hierarchical decisionmaking process that results in animals living in a restricted set of environmental conditions (Partridge 1978, Block and Brennan 1993). Animals make a series of species-consistent decisions on the basis of different sets of criteria for each scale (Orians and Wittenberger 1991, Bergin 1992). Birds with a wide geographic range, such as most seabirds (Buckley and Buckley 1980), may use either similar habitats in all regions or may select different sites from region to region (Cody 1985). In addition, birds may select similar physiognomic characteristics, despite differences in available

3E-mail: pgborbor@cenpat.edu.ar vegetation species, vegetation cover, substrate types, or other physical characteristics (Burger and Gochfeld 1988).

Larus gulls are largely temperate-zone species that nest colonially, and many show great plasticity in their habitat requirements (Burger and Gochfeld 1996). Many studies of habitat selection in gulls analyzed only one or few colonies (e.g. Burger and Shisler 1978, Montevecchi 1978), which restricts the ability to identify the habitat that gulls use for colonies and nest habitats and makes it difficult to examine the flexibility in habitat choices (Burger and Gochfeld 1981). To determine how variability influences habitat choice requires studies that encompass a range of environments broad enough for the effects of variability to be evident (Orians and Wittenberger 1991). 
Kelp Gulls (Larus dominicanus) are widely distributed in the Southern Hemisphere, breeding in South America, southern Africa, Australia, New Zealand, subantarctic islands, and Antarctic Peninsula (Burger and Gochfeld 1996). In Argentina, that species is widely distributed and abundant, breeding along the Atlantic coast (Yorio et al. 1999). Its nesting habitat requirements have not been analyzed in Argentina, apart from nest-site selection at a single colony in central Patagonia (Yorio et al. 1995). Elsewhere, Kelp Gulls nest in varying habitat types (Fordham 1964, Lazo et al. 1992, Yorio et al. 1995, Simeone and Bernal 2000) with a preference for areas with vegetation cover (Burger and Gochfeld 1981, Quintana and Travaini 2000). Vegetative structure is frequently the primary proximate factor determining where and how many bird species use resources (Block and Brennan 1993).

Kelp Gull populations in Argentina have expanded during the last two decades, which may negatively affect other coastal species through predation, competition for breeding space, and kleptoparasitism, and their activity at or near cities may result in hazards to aircraft and threats to human health (Yorio et al. 1998a). Knowledge of their habitat requirements will contribute to management and conservation actions, particularly with respect to spatial interactions with other species. Here we describe the nesting habitat of Kelp Gulls breeding in coastal central and northern Patagonia, Argentina, compare characteristics across colonies to identify critical habitat selection factors, and examine the importance of vegetation cover.

\section{Methods}

Kelp Gull breeding habitat was analyzed along $\sim 2,500 \mathrm{~km}$ of coastline from Islote Canal Ancla $\left(38^{\circ} 56^{\prime} \mathrm{S}, 62^{\circ} 11^{\prime} \mathrm{W}\right)$ to Isla Quintano $\left(45^{\circ} 15^{\prime} \mathrm{S}, 66^{\circ} 42^{\prime} \mathrm{W}\right.$; Appendix; Fig. 1). Information was gathered on colony size and habitat composition during late incubation (November or December, depending on the colony) between 1998 and 2001 at 25 colonies, and census data was obtained from a further 43 colonies

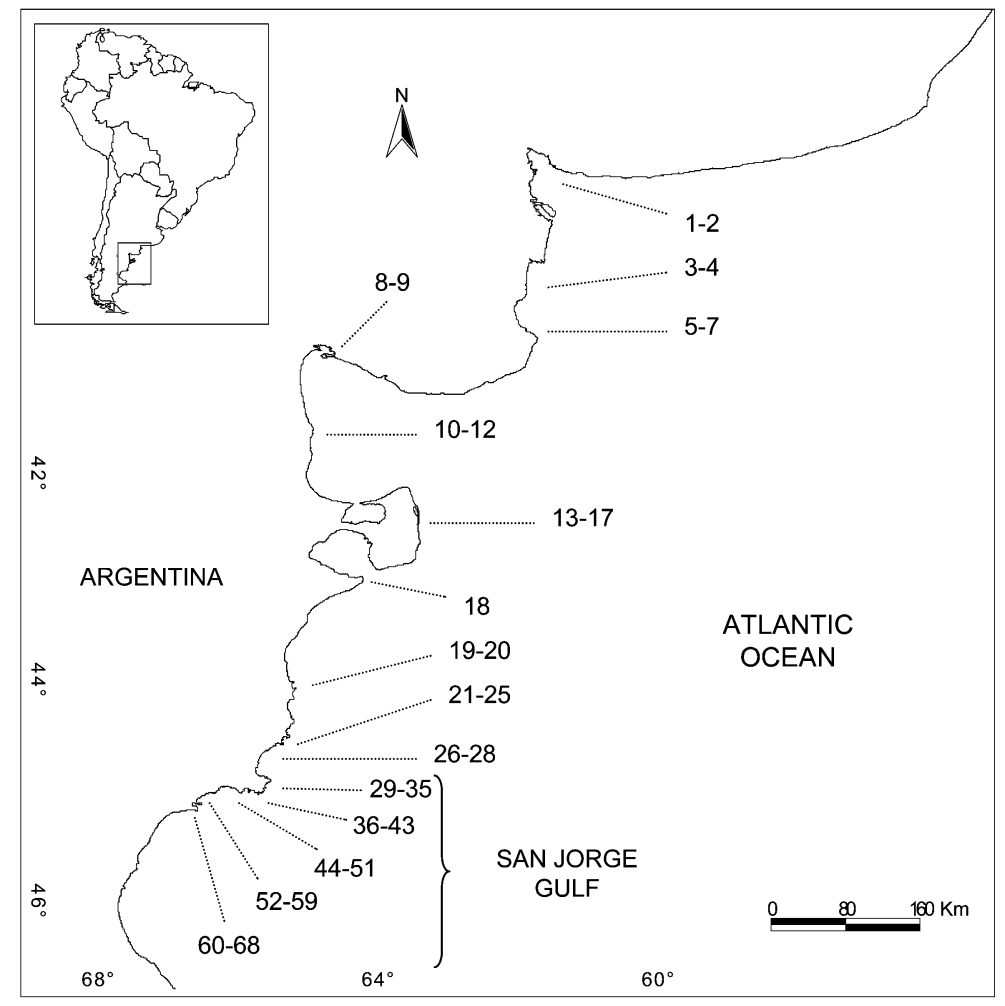

FIG. 1. Map of northern and central coastal Patagonia, Argentina, showing the location of Kelp Gull colonies. Numbers correspond to sites in Appendix. 
visited in 1993-1995 (Yorio et al. 1998b; Appendix). Complete nest counts were made at all colonies, except Isla Vernacci Sudoeste and Isla Vernacci Este, where nests were estimated using randomly chosen $100 \mathrm{~m}^{2}$ circular plots ( $n=40$ and 23 , respectively). We considered a nest active when it contained nesting material or contained an egg. A compass and a measuring tape was used to map colonies and calculate their areas.

The coastline of the study area was divided into $30 \mathrm{~km}$ sectors. At each breeding locality, visited information was obtained on topography, soil composition, and vegetation. To characterize the nesting habitat, the following categories were considered: vegetated areas with shrubs, grass, or grass-herbs; bare ground with different soil composition (silt-clay, sand, shell, gravel, and rock fragments); rock; and rocky cliff ledges. Slope was categorized as steep $\left(>15^{\circ}\right)$, medium $\left(5-15^{\circ}\right)$ or low $\left(<5^{\circ}\right)$. We recorded the presence of other breeding seabirds: Magellanic Penguin (Spheniscus magellanicus), Southern Giant Petrel (Macronectes giganteus), Imperial Cormorant (Phalacrocorax atriceps), Rock Shag (P. magellanicus), Neotropic Cormorant ( $P$. brasilianus), Dolphin Gull (L. scoresbii), Olrog's Gull (L. atlanticus), South American Tern (Sterna hirundinacea), Royal Tern (S. maxima), Cayenne Tern (S. eurygnatha) and skuas (Catharacta antarctica and C. chilensis, considered as Catharacta spp. here). The association with the South American sea lion (Otaria flavescens) and South American fur seal (Arctocephalus australis) was also analyzed using data from Reyes et al. (1999) and E. Crespo (unpubl. data).

Because most colonies in northern and central Patagonia were on islands, island use was studied in detail at the northern sector of the San Jorge Gulf, Chubut Province $\left(44^{\circ} 54^{\prime} \mathrm{S}, 65^{\circ} 32^{\prime} \mathrm{W}\right.$ to $45^{\circ} 15^{\prime} \mathrm{S}$, $66^{\circ} 42^{\prime} \mathrm{W}$ ), characterized by numerous islands. Habitat information was analyzed from 40 and 12 islands with and without breeding Kelp Gulls, respectively (Appendix). Digital data was used from a Landsat TM satellite image to estimate island size, distance to the closest mainland, and the area covered by each of five habitat types (García Borboroglu et al. 2002): rocky outcrops; grass steppe; shrub steppe; open outcrops of friable materials such as sand, silt-clay and shell; and gravel deposits.

Nesting substrate was assessed at subsamples of 12 island colonies (Appendix) and 12 islands without colonies. At each site, the percentage of substrate components was estimated in the surface layer (top $5 \mathrm{~cm}$ ) at $100 \mathrm{~m}^{2}$ regularly distributed circular plots, following Stokes and Boersma (1991). Substrate components were classified as silt-clay, sand, shell fragments, gravel and rock fragments, and rock (exposed bedrock).

At 15 colonies distributed throughout the study area (Appendix), vegetation cover was visually estimated in $100 \mathrm{~m}^{2}$ circular plots located within the colony boundaries and at randomly selected areas (within and outside the colony boundaries) for comparison. Within areas with vegetation at four colonies, the vegetation cover was also compared between areas used (60 plots), and not used (45 plots) by breeding Kelp Gulls. In 12 colonies, information was obtained of the area covered by habitats with and without vegetation and the number of breeding pairs at those habitats (Appendix), constituting 30\% of the total population for the entire study area.

Statistical analyses. - Differences in habitat characteristics between occupied and unoccupied locations were tested using the Mann-Whitney $U$-test. The relationship between variables, such as colony size, island area, and vegetation cover, was analyzed using the Spearman rank-order correlation. Generalized linear models (GLM; Baker and Nelder 1978) was used to assess which explanatory variables, their interactions, or both that best explained the variation in the presence or absence of breeding Kelp Gulls on islands. The explanatory variables were fitted to the observed data using the forward stepwise branching modelling procedure (Tella et al. 1999). Two GLM analyses were conducted: the first used data on island characteristics obtained from the satellite image (see above) and the second used data on substrate composition obtained from field samples. The presence or absence of Kelp Gulls was used as the response variable in both models, and all of the habitat variables named above as the explanatory variables. We considered a binomial distribution of errors and a logistic link (equivalent to a logistic regression). The strength of the association between Kelp Gulls and other seabird and pinniped species was analyzed using the phi association coefficient (Krebs 1978). Underlying assumptions of the statistical tests were verified in all cases and nonparametric tests were performed when logarithmic and arcsine transformations did not approach normal distributions. Values reported are means \pm SD.

\section{Results}

Eighty percent of the 68 Kelp Gull colonies were on islands. The eight continental colonies were between Punta Delgada $\left(42^{\circ} 43^{\prime} \mathrm{S}, 63^{\circ} 38^{\prime} \mathrm{W}\right)$ and Cabo San José $\left(44^{\circ} 31^{\prime} \mathrm{S}, 65^{\circ} 17^{\prime} \mathrm{W}\right)$ where no islands were available. Islands were absent in $82 \%$ of the coastal sectors without Kelp Gull colonies. The probability of finding a colony was significantly higher in coastal sectors with islands $\left(\chi^{2}=5.76, \mathrm{df}=1, P=0.02\right)$. In sectors with islands, there was a significantly higher probability that gulls bred on islands $\left(\chi^{2}=13.47\right.$, $\mathrm{df}=1, P<0.001)$.

Fifty-nine percent of the colonies were located in the northern sector of San Jorge Gulf. Here all colonies were on islands and occurred 
on $40(77 \%)$ of the 52 available islands. Colonies were located on islands in all size categories (Fig. 2A). Average area was similar for islands with (range 0.7-599.4 ha; median $=6.3 \mathrm{ha}$ ) and without (0.3 and 421.1 ha; median $=3.5$ ha) breeding Kelp Gulls (Mann-Whitney, $Z=0.72$, $P=0.47)$. Number of breeding pairs per colony was positively correlated with island area $\left(r_{\mathrm{s}}=\right.$ $0.34, P=0.04, n=39$ )

Islands supporting Kelp Gull colonies (range 0.5-13.3 km; median $=2.1 \mathrm{~km}$ ) were located significantly further from the mainland than islands lacking colonies (range 0.3-5.4 km; median $=1.0$ km; Fig 2B; Mann-Whitney, $Z=2.18$, $P=0.029$ ). Kelp Gulls nested in all the 10 islands located farther than $6 \mathrm{~km}$ from the continent, whereas only $61 \%$ of the 26 islands $<2 \mathrm{~km}$ were occupied (Fig. 2B).

Kelp Gulls use a wide range of nesting habitats, including areas with shrub or grass-herb vegetation with different degrees of cover, open outcrops devoid of vegetation and with different substrates, areas with gentle or steep slopes, and cliffs. In $68 \%$ of the 68 colonies, the gulls occupied more than one of those habitat types. Nests were found in vegetated habitats in 55\% of the colonies, usually among shrubs $1.2 \mathrm{~m}$ tall (range $0.2-3.0 \mathrm{~m}, n=519, \mathrm{SD}=1.8 \mathrm{~m}$ ). At a few colonies, open space among shrubs was covered by grass or herbs.

Gulls also nested on beaches, sandbars, or headlands devoid of vegetation. Nests were located on bare rocky habitats in $68 \%$ of the 68 colonies, sometimes with rocks providing nest cover. Bare ground with other substrate components was used less frequently: gulls nested on gravel, sand, silt-clay, and mixed sand-shell substrates at $35 \%, 20 \%, 4.5 \%$, and $27 \%$ of the colonies, respectively. Availability of those substrates was $79 \%, 58 \%, 42 \%, 31 \%$, and $39 \%$, respectively. Slope at the colonies was rated as low (79\% of 68 colonies), medium $(40 \%)$,
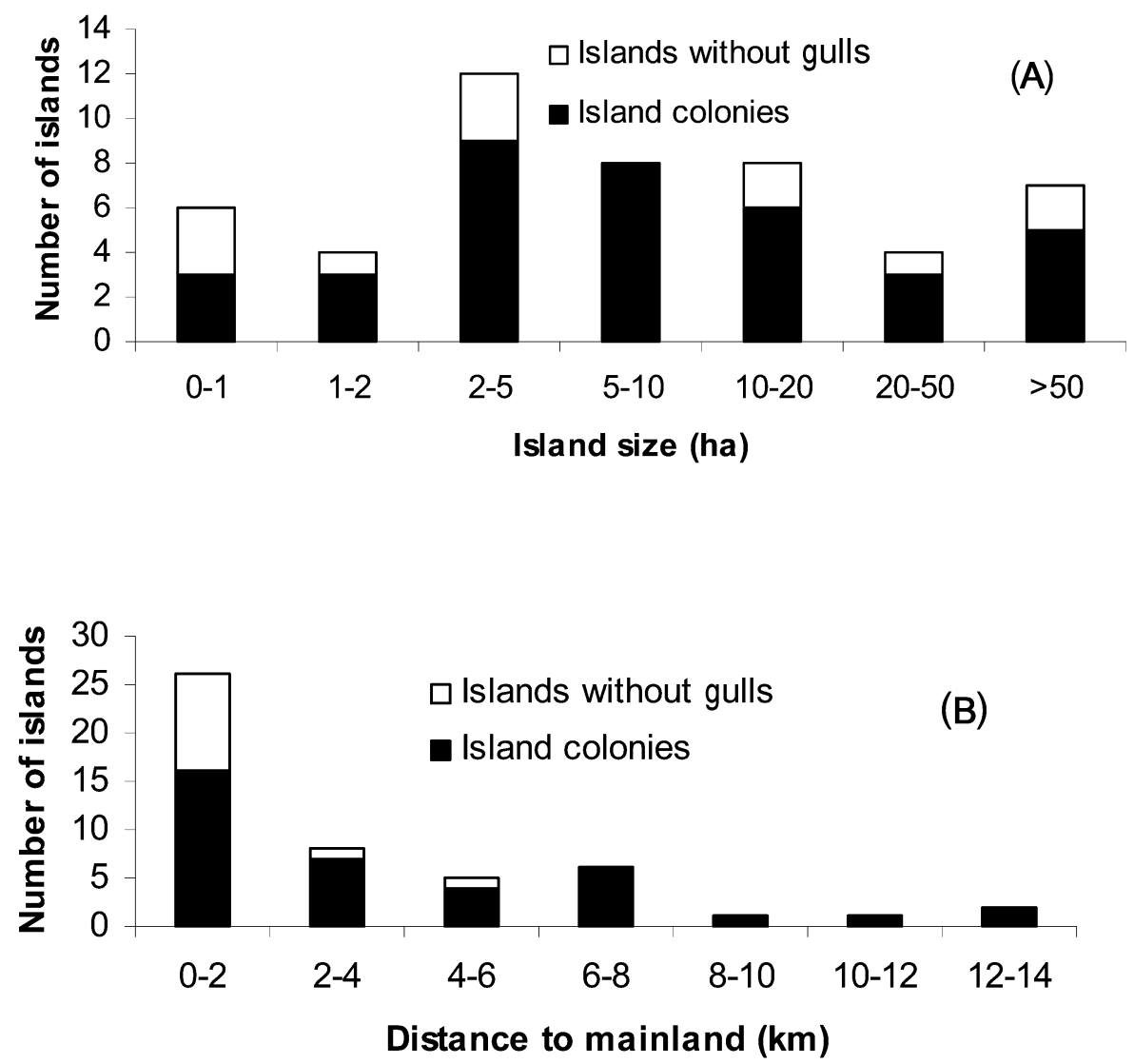

FIg. 2. (A) Average size and (B) distance to the mainland of islands with and without colonies of Kelp Gulls at northern and central coastal Patagonia, Argentina. 
or steep (7\%). Nests were on rocky cliff ledges at continental colonies (Punta Delgada, Playa La Pastosa, Punta Pirámide, Punta León, and Punta Ezquerra), but on only one island (Pan de Azúcar Island).

Islands with and without Kelp Gull colonies showed similar habitat types (Table 1). The best GLM model using satellite imagery data showed that the probability of occupation of an island increases with the distance to the mainland and with the amount of shrub-type vegetation cover (Fig. 3). This model (which explained $23 \%$ of the deviance; $\mathrm{df}=49$ ) gave the following function for the linear predictor (LP) of the logistic equation: $\mathrm{LP}=-0.926(\mathrm{SE}=0.594)+0.428$
$(\mathrm{SE}=0.222) \times$ distance to mainland $+0.049(\mathrm{SE}=$ $0.026) \times$ area covered by shrubs.

Vegetation cover varied from $0 \%$ to $90 \%$ among colonies. Kelp Gulls tended to nest in areas with higher or equal cover than randomly selected areas (Fig. 4). At 15 colonies, vegetation cover at occupied areas (mean $21 \pm 26 \%, n=531$ ) was statistically higher than at random areas $(16 \pm 22 \%, n=402$; Mann-Whitney, $Z=2.75$, $P<0.01)$. Vegetation cover was $<30 \%$ at $73 \%$ of 15 colonies and exceeded $30 \%$ only at Banco Nordeste, Islote Arroyo Jabalí Este, Islote La Pastoza, and Islote de los Pájaros (Fig. 4). The satellite image showed that the average proportion of island area with vegetation was

TABLE 1. Percentage of area covered by each habitat type and percentage of substrate components at islands with and without nesting Kelp Gulls in northern San Jorge Gulf (means with SD in parentheses; $n=$ number of locations analyzed for habitat type and number of sample plots for substrate components).

\begin{tabular}{lccc}
\hline \hline & Islands with gulls & Islands without gulls & Mann-Whitney U-test \\
\hline Habitat type & $(\boldsymbol{n}=\mathbf{3 7 )}$ & $\mathbf{( n = 1 2 )}$ & \\
Rocky outcrops (\%) & $60(30.4)$ & $66.8(36.5)$ & $Z=1.22, P=0.22$ \\
Grass steppe & $9.4(10.5)$ & $10.6(14.3)$ & $Z=0.12, P=0.90$ \\
Shrub steppe & $17.7(23.1)$ & $5.9(11.9)$ & $Z=2.04, P=0.07$ \\
Open outcrops (\%) b & $1.5(5.4)$ & $0(0.0)$ & $Z=0.70, P=0.49$ \\
Gravel deposits (\%) b & $11.4(17.1)$ & $16.7(38.9)$ & $Z=1.20, P=0.24$ \\
Substrate component & $(\boldsymbol{n = 1 8 7 )}$ & $(\boldsymbol{n = 2 9 1 )}$ & $Z=3.26, P=0.001$ \\
Silt-clay & $52.7(29.6)$ & $9.0(20.7)$ & $Z=2.28, P=0.02$ \\
Sand & $14.9(19.3)$ & $2.8(6.2)$ & $Z=1.41, P=0.16$ \\
Shell & $13.6(12.2)$ & $7.1(20.0)$ & $Z=0.83, P=0.40$ \\
Gravel & $4.6(4.0)$ & $7.2(11.1)$ & $Z=3.06, P<0.01$ \\
Rock & $14.0(13.3)$ & $73.9(38.6)$ & \\
\hline
\end{tabular}

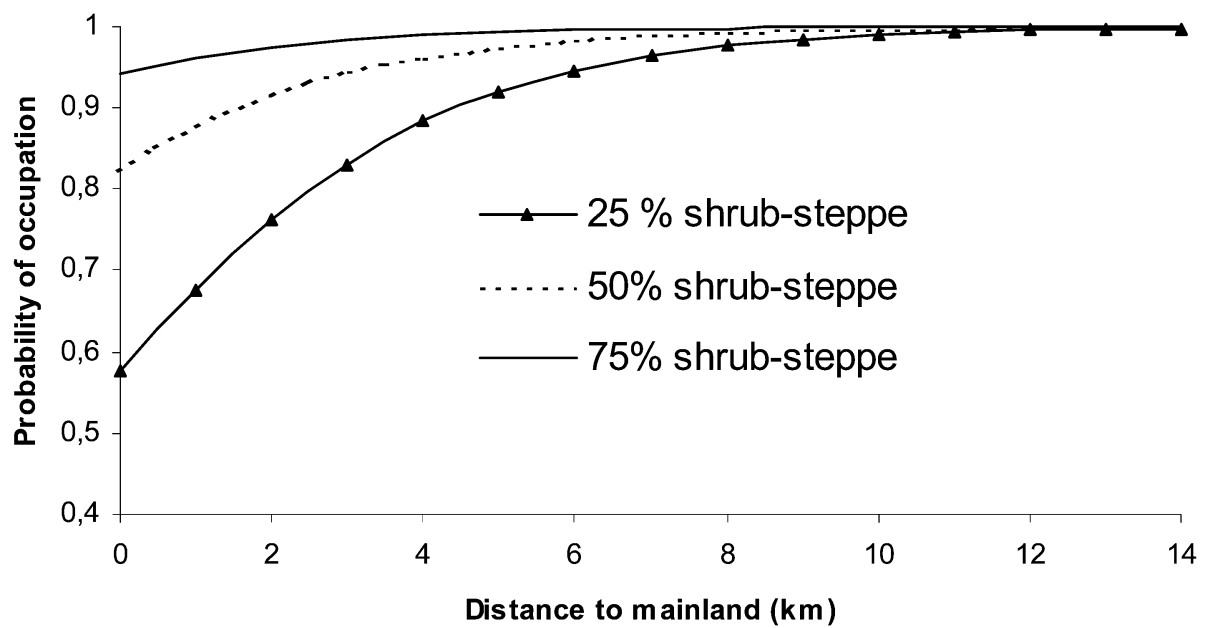

FIG. 3. Probability of occupation of an island by Kelp Gulls for breeding with respect to the distance to the mainland and the amount of surface covered by shrub-type vegetation, as predicted by the GLM model. 


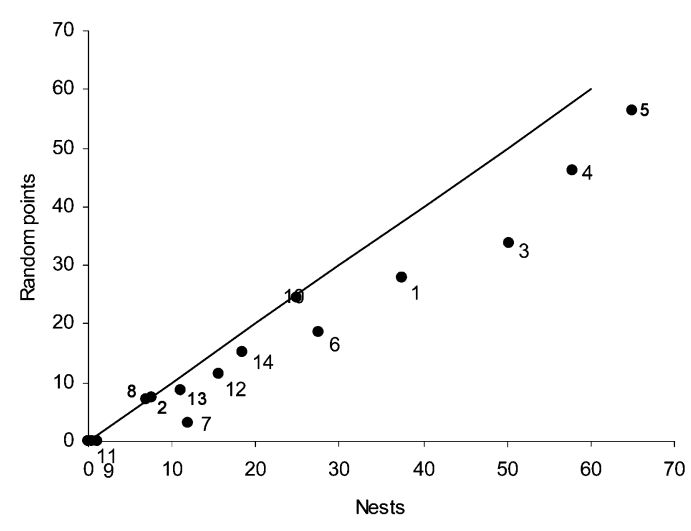

FIg. 4. Percentage of vegetation cover for areas around nests and randomly selected areas within Kelp Gull colonies. Solid line indicates equivalency. Colonies numbered as in Appendix.

low $(15 \%)$. However, proportion of nests in vegetated habitats $(56 \%, n=14,238$ nests, 12 colonies) was significantly higher than that expected $(15 \%)$ if gulls nested according to the percent of the available area $\left(P\left[\chi^{2}\right]<0.01\right)$. Within vegetated areas, Kelp Gulls avoided the densest vegetation, preferring areas with lower cover (mean $17 \pm 19 \%, n=60$ plots) compared to areas not used for nesting $(68 \pm 21 \%, n=45$ plots; Mann-Whitney, $Z=-7.82 ; P<0.001)$.

In northern San Jorge Gulf, univariate analysis showed that the proportions of silt-clay and sand substrates were significantly higher, and rocky substrates significantly lower, on islands with colonies than on islands without colonies (Table 1). The best GLM model for explaining the presence of gulls using substrate data obtained from field sample plots indicated that the probability of occupation of an island increased with the amount of silt-clay and sand in the substrate. The model, which explained $67 \%$ of the deviance $(\mathrm{df}=24)$, produced the following linear predictor function: $\mathrm{LP}=-6.08(\mathrm{SE}=3.88)+$ $0.09(\mathrm{SE}=0.05) \times$ silt-clay percentage $+0.27(\mathrm{SE}=$ $0.18) \times$ sand percentage.

Kelp Gulls nested in association with other seabird species in 46 of the 68 colonies (Appendix). The Kelp Gull showed a significant positive association only with the Olrog's Gull $\left(\phi=0.21, P\left[\chi^{2}\right]=0.04\right)$, and a negative association (avoidance) only with South American Terns $\left(\phi=-0.35, \chi^{2}<0.01\right)$. No significant associations were found with sea lions or fur seals.
Discussion

Our study constitutes the most comprehensive analysis of nesting habitat use in the Kelp Gull, which is the most widespread and abundant gull of the Southern Hemisphere. Kelp Gulls used a wide variety of habitats, including areas with different slopes and degrees of vegetation cover located on island or mainland sites. Our results in Argentina confirm that Kelp Gulls are generalists with respect to breeding habitat as observed elsewhere in the Southern Hemisphere, including southern Africa (Burger and Gochfeld 1981, Crawford et al. 1982), New Zealand (Fordham 1964), Antarctica (Lazo et al. 1992, Quintana and Travaini 2000), and Chile (Simeone and Bernal 2000). The plasticity of habitat use in Kelp Gulls is demonstrated not only by their ability to use a broad spectrum of habitats available at each location, but also by the diversity of habitats used throughout its range.

In central and northern Patagonia, breeding Kelp Gulls showed a strong preference for islands, with continental colonies found only in coastal sectors where islands were not available. Kelp Gulls nesting on those mainland sites used cliffs or steep slopes that lessened the potential risk from ground predators, such as the hairy armadillo (Chaetophractus villosus), Argentine gray fox (Pseudalopex griseus), red fox (Ps. culpaeus), Patagonian ferret (Galictis cuja), and Geoffroy's cat (Felis geoffroyi). Seabirds generally breed at sites, such as islands or cliffs, which are inaccessible to mammalian predators and where human presence and disturbance is scarce (Lack 1968, Partridge 1978, Buckley and Buckley 1980). In addition, Kelp Gulls selected islands farther from the mainland.

Vegetation cover was a key component of nesting habitat for Kelp Gulls in Argentina. The amount of vegetated habitat increased the probability of occupation of an island, and that type of habitat was preferred in comparison to areas devoid of vegetation. Similarly, in New Zealand, most Kelp Gull nests were among or under shrubs or in grass-herb vegetation (Fordham 1964). On the Antarctic Peninsula, Kelp Gulls nested in terraces covered by grasses, in preference to moss-covered patches or exposed pebble beaches (Quintana and Travaini 2000). In South Africa, cover was one of the most consistently important habitat features selected by Kelp 
Gulls (Burger and Gochfeld 1981). Preference for vegetation cover seems to relate directly to both offspring and adult survival (Burger and Gochfeld 1981), because cover determines the thermal properties of the nest and influences the risk of predation (Parsons 1982, Parsons and Chao 1983).

Although vegetation was important, Kelp Gulls in Argentina avoided areas of dense vegetation. Similar results have been found with Kelp Gulls in South Africa (Burger and Gochfeld 1981) and other gull species elsewhere (Burger 1974, Burger and Shisler 1978). Areas with intermediate cover have been found to give improved breeding success in Lesser Black-backed Gulls (L. fuscus) (Davis and Dunn 1976) and Kelp Gulls (P. García Borboroglu and P. Yorio unpubl. data). Intermediate cover offers attending adults a relatively open view to detect approaching predators or attacking neighbors, allows adults to watch their offspring, and provides enough space for both fleeing chicks and adults to avoid getting tangled or injured in branches (Buckley and Buckley 1980).

Substrate affects the survival and growth of bushes. The substrate at islands with Kelp Gull colonies in Argentina showed a significantly higher percentage of silt-clay and sand, which probably allows better plant growth. Islands supporting Kelp Gull colonies had less exposed rock than islands lacking them. The absence or lower quantity of shrub-type vegetation on those islands probably makes them less attractive for nesting.

We found a positive breeding association between Kelp and Olrog's gulls, which is a threatened species with a restricted distribution (Collar et al. 1994). Considering the current increase in Kelp Gull populations (Yorio et al. 1999) and their flexibility in habitat requirements (our study), future research should focus on the potential competition for breeding space between those species and the negative effects on Olrog's Gull that may arise from those interactions.

\section{AcKnowledgments}

Research was funded by grants from Wildlife Conservation Society, Consejo Nacional de Investigaciones Científicas y Técnicas, and Agencia de Promoción Científica y Tecnológica. We thank J. Owen, R. Vera, M. A. Díaz, G. Soria, M. Hernández and F. Garay for field assistance, Centro Nacional
Patagónico (CONICET) and Centro de Estudios Ambientales para la Planificación y el Desarrollo for institutional support, Soriano S. A., Prefectura Naval Argentina, Municipalidad de Punta Alta and D. Rábano for logistical support, and the Dirección de Conservación de Areas Naturales of Chubut and Dirección de Fauna y Flora of Río Negro for permits to work at protected areas.

\section{Literature Cited}

Baker, R. J., and J. A. Nelder. 1978. The GLIM system: Release 3. Royal Statistical Society, Oxford, United Kingdom.

Bergin, T. M. 1992. Habitat selection by the Western Kingbird in western Nebraska: A hierarchical analysis. Condor 94:903-911.

Block, W. M., AND L. A. Brennan. 1993. The habitat concept in ornithology, theory and applications. Current Ornithology 11:35-91.

Buckley, F. G., and P. A. Buckley. 1980. Habitat selection in marine birds. Pages 69-112 in Behavior of Marine Animals, vol. 4 (J. Burger, Ed.). Plenum Press, New York.

BuRgER, J. 1974. Breeding adaptations of Franklin's Gull Larus pipixcan to a marsh habitat. Animal Behaviour 22:521-567.

Burger, J., AND M. Gochfeld. 1981. Colony and habitat selection of six Kelp Gull Larus dominicanus colonies in South Africa. Ibis 123:298-310.

Burger, J., AND M. Gochreld. 1988. Habitat selection in Mew Gulls: Small colonies and site plasticity. Wilson Bulletin 100:395-410.

Burger, J., AND M. Gochreld. 1996. Family Laridae (Gulls). Pages 572-623 in Handbook of the Birds of the World, Hoatzin to Auks, vol. 3 (J. del Hoyo, A. Elliott, and J. Sartagal, Eds.). Lynx Edicions, Barcelona, Spain.

Burger, J., ANd J. Shisler. 1978. Nest-site selection and competitive interactions of Herring and Laughing gulls in New Jersey. Auk 95: 252-266.

Cody, M. L. 1985. An introduction to habitat selection in birds. Pages 3-56 in Habitat Selection in Birds (M. L. Cody, Ed.). Academic Press, New York.

Collar, N., M. J. Crosby, and A. J. Stattersfield. 1994. Birds to Watch 2: The World List of Threatened Birds. BirdLife International, Cambridge, United Kingdom.

Crawford, R. J. M., J. Cooper, and P. A. Shelton. 1982. Distribution, population size, breeding and conservation of the Kelp Gull in Southern Africa. Ostrich 53:164-177.

Davis, J. W. F., AND E. K. Dunn. 1976. Intraspecific predation and colonial breeding in Lesser Black-backed Gulls, Larus fuscus. Ibis 118: 65-77. 
Fordham, R. A. 1964. Breeding biology of the Southern Black-backed Gull. I: Pre-egg and egg stage. Notornis 11:3-34.

García Borboroglu, P., P. Yorio, P. D. Boersma, H. Del Valle, and M. Bertellotti. 2002. Habitat use and breeding distribution of Magellanic Penguins in northern San Jorge Gulf, Patagonia, Argentina. Auk 119:233-239.

Krebs, C. J. 1978. Ecology: The Experimental Analysis of Distribution and Abundance. Harper, New York.

LACK, D. 1968. Ecological Adaptations for Breeding in Birds. Metheun, London.

Lazo, I., H. NúÑez, ANd J. YÁnez. 1992. Áreas libres de hielo y su relación y su relación con ensambles de aves nidificantes antárticas, Isla Livingston, Antártica. Serie Científica (Instituto Antártico Chileno) 42:69-75.

Montevecchi, W. A. 1978. Nest site selection and its survival value among Laughing Gulls. Behavioral Ecology and Sociobiology 4: 143-161.

Orians, G. H., and J. F. Wittenberger. 1991. Spatial and temporal scales in habitat selection. American Naturalist 137:529-549.

Parsons, J. 1982. Nest-site habitat and hatching success of gulls. Colonial Waterbirds 5:131-138.

Parsons, K. C., and J. Chao. 1983. Nest cover and chick survival in Herring Gulls (Larus argentatus). Colonial Waterbirds 6:154-159.

Partridge, L. 1978. Habitat selection. Pages 351376 in Behavioural Ecology (J. R. Krebs and N. B. Davies, Eds.). Blackwell Scientific, Oxford.

Quintana, R. D., and A. Travaini. 2000. Characteristics of nest sites of skuas and Kelp Gull in the Antarctic Peninsula. Journal of Field Ornithology 71:236-249.

Reyes, L., E. Crespo, and V. Szapkievich. 1999. Distribution and population size of the Southern sea lion (Otaria flavescens) in central and southern Chubut, Patagonia, Argentina. Marine Mammal Science 15:478-493.

Simeone, A., ANd M. Bernal. 2000. Effects of habitat modification of breeding seabirds: A case study in central Chile. Waterbirds 23:449-456.

Stokes, D. L., AND P. D. Boersma. 1991. Effects of substrate on the distribution of Magellanic Penguins (Spheniscus magellanicus) burrows. Auk 108:922-933.

Tella, J. L., G. Blanco, M. G. Forero, A. Gajón, J. A. Donázar, and F. Hiraldo. 1999. Habitat, world geographic range, and embryonic development of hosts explain the prevalence of avian hematozoa at small spatial and phylogenetic scales. Proceedings of the National Academy of Sciences USA 96:1785-1789.

Yorio, P., M. Bertellotti, P. Gandini, and E. Frere. 1998a. Kelp gulls (Larus dominicanus) breeding on the argentine coast: Population status and a review of its relationship with coastal management and conservation. Marine Ornithology 26:11-18.

Yorio, P., M. Bertellotti, and F. Quintana. 1995. Preferences for covered nest sites and breeding success in Kelp Gulls Larus dominicanus. Marine Ornithology 23:121-128.

Yorio, P., E. Frere, P. Gandini, and W. Conway. 1999. Status and conservation of seabirds breeding in Argentina. Bird Conservation International 9:299-314.

Yorio, P., E. Frere, P. Gandini, and G. Harris, EDs. 1998b. Atlas de la distribución reproductiva de aves marinas en el litoral Patagónico Argentino. Plan de Manejo Integrado de la Zona Costera Patagónica. Fundación Patagonia Natural and Wildlife Conservation Society. Instituto Salesiano de Artes Gráficas, Buenos Aires, Argentina.

Associate Editor: A. E. Burger 
APPENDIX. Location, colony size (number of breeding pairs), variables measured, and seabird or pinniped species breeding adjacent to Kelp Gull colonies in Argentina.

\begin{tabular}{|c|c|c|c|c|c|c|}
\hline & Breeding site & Position & $\begin{array}{l}\text { Colony size } \\
\text { (pairs) }\end{array}$ & $\begin{array}{l}\text { e Year } \\
\text { (source) }^{a}\end{array}$ & $\begin{array}{l}\text { Variables } \\
\text { measured }^{\mathrm{b}}\end{array}$ & $\begin{array}{c}\text { Other } \\
\text { species }^{c}\end{array}$ \\
\hline 1 & Islote Canal Ancla & $38^{\circ} 56^{\prime} \mathrm{S}, 62^{\circ} 11^{\prime} \mathrm{W}$ & $\cong 250$ & $2001(1)$ & $\mathrm{L}$ & OG \\
\hline 2 & Isla Trinidad & $39^{\circ} 08^{\prime} \mathrm{S}, 61^{\circ} 53^{\prime} \mathrm{W}$ & 894 & $1995(2)$ & $\mathrm{L}$ & OG \\
\hline 3 & $\begin{array}{l}\text { Islote norte Isla Morro } \\
\text { de Indio }\end{array}$ & $39^{\circ} 56^{\prime} \mathrm{S}, 62^{\circ} 09^{\prime} \mathrm{W}$ & $\mathrm{NC}$ & $1995(2)$ & $\mathrm{L}$ & OG \\
\hline 4 & Isla Puestos & $39^{\circ} 58^{\prime} \mathrm{S}, 62^{\circ} 15^{\prime} \mathrm{W}$ & NC & $1995(2)$ & $\mathrm{L}$ & OG \\
\hline 5 & Banco Nordeste & $40^{\circ} 32^{\prime} \mathrm{S}, 62^{\circ} 09^{\prime} \mathrm{W}$ & $\cong 1,000$ & $2000(1)$ & $\mathrm{L}, \mathrm{V}, \mathrm{Vr}$ & OG \\
\hline 6 & Islote Arroyo Jabalí Oeste & $40^{\circ} 32^{\prime} \mathrm{S}, 62^{\circ} 17^{\prime} \mathrm{W}$ & $\cong 290$ & $2000(1)$ & $\mathrm{L}, \mathrm{V}, \mathrm{Vr}$ & OG \\
\hline 7 & Islote Arroyo Jabalí Este & $40^{\circ} 32^{\prime} \mathrm{S}, 62^{\circ} 16^{\prime} \mathrm{W}$ & $\cong 350$ & $2000(1)$ & $\mathrm{L}, \mathrm{V}, \mathrm{Vr}$ & - \\
\hline 8 & Isla Novaro & $40^{\circ} 45^{\prime} \mathrm{S}, 64^{\circ} 50^{\prime} \mathrm{W}$ & 66 & $1994(2)$ & L & ST \\
\hline 9 & Islotes del Canal Escondido & $40^{\circ} 47^{\prime} \mathrm{S}, 64^{\circ} 47^{\prime} \mathrm{W}$ & 351 & $1994(2)$ & $\mathrm{L}$ & ST \\
\hline 10 & Islote La Pastosa & $41^{\circ} 25^{\prime} \mathrm{S}, 65^{\circ} 02^{\prime} \mathrm{W}$ & 1,140 & $1995(2)$ & $\mathrm{L}, \mathrm{V}, \mathrm{Vr}$ & - \\
\hline 11 & Islote Redondo & $41^{\circ} 26^{\prime} \mathrm{S}, 65^{\circ} 01^{\prime} \mathrm{W}$ & 854 & $1995(2)$ & $\mathrm{L}$ & - \\
\hline 12 & Islote de los Pájaros & $41^{\circ} 27^{\prime} \mathrm{S}, 65^{\circ} 02^{\prime} \mathrm{W}$ & 540 & $1995(2)$ & $\mathrm{L}, \mathrm{V}, \mathrm{Vr}$ & $\mathrm{NC}$ \\
\hline 13 & Islote Notable & $42^{\circ} 25^{\prime} \mathrm{S}, 64^{\circ} 31^{\prime} \mathrm{W}$ & 4,714 & $2000(1)$ & $\mathrm{L}, \mathrm{V}, \mathrm{Vr}$ & $\mathrm{MP}, \mathrm{RS}, \mathrm{NC}$ \\
\hline 14 & Isla Primera de Caleta Valdés & $42^{\circ} 21^{\prime} \mathrm{S}, 63^{\circ} 37^{\prime} \mathrm{W}$ & $\cong 700$ & $2000(1)$ & $\mathrm{L}, \mathrm{V}, \mathrm{Vr}$ & MP \\
\hline 15 & Punta Delgada & $42^{\circ} 43^{\prime} \mathrm{S}, 63^{\circ} 38^{\prime} \mathrm{W}$ & 90 & $2000(1)$ & $\mathrm{L}$ & $\mathrm{RS}, \mathrm{NC}, \mathrm{O}$ \\
\hline 16 & Playa La Pastosa & $42^{\circ} 50^{\prime} \mathrm{S}, 63^{\circ} 59^{\prime} \mathrm{W}$ & 220 & $2000(1)$ & $\mathrm{L}, \mathrm{V}, \mathrm{Vr}$ & $\mathrm{O}$ \\
\hline 17 & Punta Pirámide & $42^{\circ} 35^{\prime} \mathrm{S}, 64^{\circ} 17^{\prime} \mathrm{W}$ & 124 & $2000(1)$ & $\mathrm{L}, \mathrm{V}, \mathrm{Vr}$ & RS,ST,O \\
\hline 18 & Punta León & $43^{\circ} 04^{\prime} \mathrm{S}, 64^{\circ} 29^{\prime} \mathrm{W}$ & 5,641 & $1999(1)$ & $\mathrm{L}, \mathrm{V}, \mathrm{Vr}$ & IC,RS,GC,NC,CT,RT,O \\
\hline 19 & Punta Clara & $43^{\circ} 58^{\prime} \mathrm{S}, 65^{\circ} 15^{\prime} \mathrm{W}$ & 39 & $1995(2)$ & $\mathrm{L}$ & $\mathrm{MP}, \mathrm{O}$ \\
\hline 20 & Punta Tombo & $44^{\circ} 02^{\prime} \mathrm{S}, 65^{\circ} 11^{\prime} \mathrm{W}$ & 5,423 & $1994(2)$ & $\mathrm{L}, \mathrm{V}, \mathrm{Vr}$ & MP,IC,RS,DG,ST,CT,S,O \\
\hline 21 & Punta Gutiérrez & $44^{\circ} 24^{\prime} \mathrm{S}, 65^{\circ} 16^{\prime} \mathrm{W}$ & 347 & $1995(2)$ & $\mathrm{L}$ & $\mathrm{IC}, \mathrm{RS}, \mathrm{ST}, \mathrm{CT}, \mathrm{O}$ \\
\hline 22 & Cabo San José & $44^{\circ} 31^{\prime} \mathrm{S}, 65^{\circ} 17^{\prime} \mathrm{W}$ & 108 & $1995(2)$ & $\mathrm{L}$ & $\mathrm{O}$ \\
\hline 23 & Isla Sur Cabo San José & $44^{\circ} 31^{\prime} \mathrm{S}, 65^{\circ} 18^{\prime} \mathrm{W}$ & 684 & $1995(2)$ & $\mathrm{L}$ & - \\
\hline 24 & Isla Acertada & $44^{\circ} 02^{\prime} \mathrm{S}, 65^{\circ} 11^{\prime} \mathrm{W}$ & 94 & $1995(2)$ & $\mathrm{L}$ & $\mathrm{O}$ \\
\hline 25 & Isla Cumbre & $44^{\circ} 35^{\prime} \mathrm{S}, 65^{\circ} 22^{\prime} \mathrm{W}$ & 1,195 & $1994(2)$ & $\mathrm{L}$ & $\mathrm{MP}, \mathrm{IC}, \mathrm{RS}, \mathrm{GC}, \mathrm{DG}, \mathrm{O}$ \\
\hline 26 & Isla Blanca Mayor & $44^{\circ} 46^{\prime} \mathrm{S}, 65^{\circ} 38^{\prime} \mathrm{W}$ & 1,035 & $1994(2)$ & $\mathrm{L}$ & $\mathrm{MP}, \mathrm{IC}, \mathrm{RS}, \mathrm{S}, \mathrm{O}$ \\
\hline 27 & Isla Blanca Menor Oeste & $44^{\circ} 46^{\prime} \mathrm{S}, 65^{\circ} 39^{\prime} \mathrm{W}$ & 278 & $1994(2)$ & $\mathrm{L}$ & RS,DG,O \\
\hline 28 & Isla Blanca Menor Este & $44^{\circ} 46^{\prime} \mathrm{S}, 65^{\circ} 38^{\prime} \mathrm{W}$ & 15 & $1994(2)$ & $\mathrm{L}$ & $\mathrm{O}$ \\
\hline 29 & Isla Moreno & $44^{\circ} 54^{\prime} \mathrm{S}, 65^{\circ} 32^{\prime} \mathrm{W}$ & 189 & $1994(2)$ & $\mathrm{L}, \mathrm{S}$ & MP,IC,RS,DG,O \\
\hline 30 & Isla Sola & $44^{\circ} 58^{\prime} \mathrm{S}, 65^{\circ} 33^{\prime} \mathrm{W}$ & 754 & $1995(2)$ & $\mathrm{L}, \mathrm{S}$ & - \\
\hline 31 & Isla Aguilón Norte & $45^{\circ} 00^{\prime} \mathrm{S}, 65^{\circ} 34^{\prime} \mathrm{W}$ & 22 & $1995(2)$ & $\mathrm{L}, \mathrm{S}$ & - \\
\hline 32 & Isla Arce & $45^{\circ} 00^{\prime} \mathrm{S}, 65^{\circ} 29^{\prime} \mathrm{W}$ & 1,028 & $1995(2)$ & $\mathrm{L}, \mathrm{S}$ & $\mathrm{MP}, \mathrm{GP}, \mathrm{IC}, \mathrm{DG}, \mathrm{O}$ \\
\hline 33 & Isla Rasa & $45^{\circ} 06^{\prime} \mathrm{S}, 65^{\circ} 23^{\prime} \mathrm{W}$ & $\mathrm{NC}$ & $1994(2)$ & $\mathrm{L}, \mathrm{S}$ & $\mathrm{IC}, \mathrm{A}$ \\
\hline 34 & Isla Leones & $45^{\circ} 03^{\prime} \mathrm{S}, 65^{\circ} 35^{\prime} \mathrm{W}$ & 437 & $1995(2)$ & $\mathrm{L}, \mathrm{S}$ & $\mathrm{MP}, \mathrm{IC}, \mathrm{RS}, \mathrm{DG}$ \\
\hline 35 & Isla Buque & $45^{\circ} 03^{\prime} \mathrm{S}, 65^{\circ} 37^{\prime} \mathrm{W}$ & 918 & $1994(2)$ & $\mathrm{L}, \mathrm{S}$ & $\mathrm{MP}, \mathrm{DG}$ \\
\hline 36 & Isla Pan de Azúcar & $45^{\circ} 04^{\prime} \mathrm{S}, 65^{\circ} 49^{\prime} \mathrm{W}$ & 1,648 & $1995(2)$ & $\mathrm{L}, \mathrm{S}$ & RS,O \\
\hline 37 & Islote Arellano & $45^{\circ} 03^{\prime} \mathrm{S}, 65^{\circ} 51^{\prime} \mathrm{W}$ & 40 & $1995(2)$ & $\mathrm{L}, \mathrm{S}$ & $\mathrm{IC}, \mathrm{RS}, \mathrm{S}, \mathrm{O}$ \\
\hline 38 & Islote Massa & $45^{\circ} 02^{\prime} \mathrm{S}, 65^{\circ} 51^{\prime} \mathrm{W}$ & 160 & $1995(2)$ & $\mathrm{L}, \mathrm{S}$ & - \\
\hline 39 & Islote Laguna & $45^{\circ} 02^{\prime} \mathrm{S}, 65^{\circ} 53^{\prime} \mathrm{W}$ & 481 & $1995(2)$ & $\mathrm{L}, \mathrm{S}$ & OG \\
\hline 40 & Islote Galfráscoli & $45^{\circ} 02^{\prime} \mathrm{S}, 65^{\circ} 51^{\prime} \mathrm{W}$ & 5 & $1995(2)$ & $\mathrm{L}, \mathrm{S}$ & - \\
\hline 41 & Islote Luisoni & $45^{\circ} 02^{\prime} \mathrm{S}, 65^{\circ} 51^{\prime} \mathrm{W}$ & 30 & $1995(2)$ & $\mathrm{L}, \mathrm{S}$ & ST,CT,RT,S \\
\hline 42 & Isla Patria & $45^{\circ} 03^{\prime} \mathrm{S}, 65^{\circ} 51^{\prime} \mathrm{W}$ & 307 & $1995(2)$ & $\mathrm{L}, \mathrm{S}$ & RS,S \\
\hline 43 & Islote frente a Patria & $45^{\circ} 02^{\prime} \mathrm{S}, 65^{\circ} 51^{\prime} \mathrm{W}$ & 10 & $1995(2)$ & $\mathrm{L}, \mathrm{S}$ & - \\
\hline 44 & Isla Tova & $45^{\circ} 06^{\prime} \mathrm{S}, 66^{\circ} 00^{\prime} \mathrm{W}$ & 772 & $1995(2)$ & $\mathrm{L}, \mathrm{S}$ & $\mathrm{MP}$ \\
\hline 45 & Isla Tovita & $45^{\circ} 07^{\prime} \mathrm{S}, 65^{\circ} 57^{\prime} \mathrm{W}$ & 153 & $1995(2)$ & $\mathrm{L}, \mathrm{S}$ & $\mathrm{MP}, \mathrm{IC}, \mathrm{NC}, \mathrm{S}, \mathrm{O}$ \\
\hline 46 & Isla Gaviota & $45^{\circ} 06^{\prime} \mathrm{S}, 65^{\circ} 58^{\prime} \mathrm{W}$ & 1,433 & $1995(2)$ & $\mathrm{L}, \mathrm{S}$ & $\mathrm{MP}$ \\
\hline 47 & Isla Este & $45^{\circ} 07^{\prime} \mathrm{S}, 65^{\circ} 56^{\prime} \mathrm{W}$ & 724 & $1995(2)$ & $\mathrm{L}, \mathrm{S}$ & $\mathrm{MP}, \mathrm{DG}, \mathrm{S}, \mathrm{O}$ \\
\hline 48 & Isla Sur & $45^{\circ} 07^{\prime} \mathrm{S}, 65^{\circ} 59^{\prime} \mathrm{W}$ & 132 & $1995(2)$ & $\mathrm{L}, \mathrm{S}$ & IC,RS \\
\hline 49 & Islotes Goëland & $45^{\circ} 05^{\prime} \mathrm{S}, 66^{\circ} 03^{\prime} \mathrm{W}$ & 825 & $1995(2)$ & $\mathrm{L}, \mathrm{S}$ & $\mathrm{S}, \mathrm{O}$ \\
\hline 50 & Isla Pequeño Robredo & $45^{\circ} 07^{\prime} \mathrm{S}, 66^{\circ} 06^{\prime} \mathrm{W}$ & 311 & $1995(2)$ & $\mathrm{L}, \mathrm{S}$ & $\mathrm{O}$ \\
\hline 51 & Isla Gran Robredo & $45^{\circ} 08^{\prime} \mathrm{S}, 66^{\circ} 03^{\prime} \mathrm{W}$ & 395 & $1995(2)$ & $\mathrm{L}, \mathrm{S}$ & GP,IC,RS,DG,S,O \\
\hline
\end{tabular}


APPENDIX. Continued.

\begin{tabular}{|c|c|c|c|c|c|c|}
\hline & Breeding site & Position & $\begin{array}{l}\text { Colony size } \\
\text { (pairs) }\end{array}$ & $\begin{array}{l}\text { e Year } \\
\text { (source) }^{a}\end{array}$ & $\begin{array}{l}\text { Variables } \\
\text { measured }^{\mathrm{b}}\end{array}$ & $\begin{array}{c}\text { Other } \\
\text { species }^{c}\end{array}$ \\
\hline 52 & Isla Lobos Oeste & $45^{\circ} 05^{\prime} \mathrm{S}, 66^{\circ} 18^{\prime} \mathrm{W}$ & 5 & $1999(1)$ & $\mathrm{L}, \mathrm{S}$ & IC,RS,DG,O \\
\hline 53 & Isla Felipe & $45^{\circ} 04^{\prime} \mathrm{S}, 66^{\circ} 19^{\prime} \mathrm{W}$ & 562 & $1999(1)$ & $\mathrm{L}, \mathrm{S}, \mathrm{N}, \mathrm{V}, \mathrm{A}$ & NC,DG,OG,S \\
\hline 54 & Isla Ezquerra Sudoeste & $45^{\circ} 04^{\prime} \mathrm{S}, 66^{\circ} 20^{\prime} \mathrm{W}$ & 145 & $1999(1)$ & $\mathrm{L}, \mathrm{S}, \mathrm{N}, \mathrm{V}, \mathrm{A}$ & IC,RS,ST,CT,RT,S \\
\hline 55 & Isla Galiano Norte & $45^{\circ} 05^{\prime} \mathrm{S}, 66^{\circ} 24^{\prime} \mathrm{W}$ & 304 & $1999(1)$ & $\mathrm{L}, \mathrm{S}, \mathrm{N}, \mathrm{V}, \mathrm{A}$ & ST,CT,RT,S,O \\
\hline 56 & Isla Galiano Central & $45^{\circ} 06^{\prime} \mathrm{S}, 66^{\circ} 25^{\prime} \mathrm{W}$ & 185 & $1999(1)$ & $\mathrm{L}, \mathrm{S}, \mathrm{N}, \mathrm{V}, \mathrm{A}$ & S \\
\hline 57 & Isla Galiano Sur & $45^{\circ} 06^{\prime} \mathrm{S}, 66^{\circ} 25^{\prime} \mathrm{W}$ & 95 & $1999(1)$ & $\mathrm{L}, \mathrm{S}, \mathrm{N}, \mathrm{V}, \mathrm{A}$ & IC,RS,S \\
\hline 58 & Isabel Norte & $45^{\circ} 06^{\prime} \mathrm{S}, 66^{\circ} 25^{\prime} \mathrm{W}$ & 116 & $1998(1)$ & $\mathrm{L}, \mathrm{S}, \mathrm{N}, \mathrm{V}, \mathrm{A}$ & CT,RT \\
\hline 59 & Isabel Sur & $45^{\circ} 06^{\prime} \mathrm{S}, 66^{\circ} 25^{\prime} \mathrm{W}$ & 108 & $1998(1)$ & $\mathrm{L}, \mathrm{S}, \mathrm{N}, \mathrm{V}, \mathrm{A}$ & IC,RS \\
\hline 60 & Isla Ceballos & $45^{\circ} 09^{\prime} \mathrm{S}, 66^{\circ} 22^{\prime} \mathrm{W}$ & 1,229 & $1999(1)$ & $\mathrm{L}, \mathrm{S}, \mathrm{N}, \mathrm{V}, \mathrm{A}$ & RS,DG,O \\
\hline 61 & Isla Vernaci Este & $45^{\circ} 11^{\prime} \mathrm{S}, 66^{\circ} 29^{\prime} \mathrm{W}$ & 2,813 & $1999(1)$ & $\mathrm{L}, \mathrm{S}, \mathrm{N}, \mathrm{V}, \mathrm{Vr}, \mathrm{Vo}, \mathrm{A}$ & MP,IC,RS,DG,ST,S,O \\
\hline 62 & Isla Vernaci Norte 2 & $45^{\circ} 11^{\prime} \mathrm{S}, 66^{\circ} 30^{\prime} \mathrm{W}$ & 56 & $1999(1)$ & $\mathrm{L}, \mathrm{S}$ & $\mathrm{MP}$ \\
\hline 64 & Isla Vernaci Sudoeste & $45^{\circ} 11^{\prime} \mathrm{S}, 66^{\circ} 31^{\prime} \mathrm{W}$ & 8,168 & $1999(1)$ & $\mathrm{L}, \mathrm{S}, \mathrm{N}, \mathrm{V}, \mathrm{Vr}, \mathrm{Vo}, \mathrm{A}$ & $\mathrm{MP}, \mathrm{NC}, \mathrm{OG}, \mathrm{O}$ \\
\hline 65 & Isla Vernaci Oeste & $45^{\circ} 11^{\prime} \mathrm{S}, 66^{\circ} 31^{\prime} \mathrm{W}$ & 93 & $1999(1)$ & $\mathrm{L}, \mathrm{S}, \mathrm{N}, \mathrm{V}, \mathrm{Vr}, \mathrm{Vo}, \mathrm{A}$ & IC,RS,DG,O \\
\hline 66 & Isla Vernaci Noroeste & $45^{\circ} 10^{\prime} \mathrm{S}, 66^{\circ} 31^{\prime} \mathrm{W}$ & 321 & $1999(1)$ & $\mathrm{L}, \mathrm{S}, \mathrm{N}, \mathrm{V}, \mathrm{Vr}, \mathrm{Vo}, \mathrm{A}$ & MP \\
\hline 63 & Isla Vernaci Nornoroeste & $45^{\circ} 11^{\prime} \mathrm{S}, 66^{\circ} 30^{\prime} \mathrm{W}$ & 34 & $1999(1)$ & $\mathrm{L}, \mathrm{S}$ & $\mathrm{MP}$ \\
\hline 67 & Isla Viana Mayor & $45^{\circ} 11^{\prime} \mathrm{S}, 66^{\circ} 24^{\prime} \mathrm{W}$ & 438 & $1993(2)$ & $\mathrm{L}, \mathrm{S}$ & MP,IC,RS,ST,CT,S,O \\
\hline 68 & Isla Quintano & $45^{\circ} 15^{\prime} \mathrm{S}, 66^{\circ} 42^{\prime} \mathrm{W}$ & 1,777 & $1995(2)$ & $\mathrm{L}, \mathrm{S}$ & IC,RS,DG,S,O \\
\hline
\end{tabular}

a Sources for colony size estimations: (1) this study, (2) Yorio et al. (1998b).

bVariables measured: $\mathrm{A}=$ area with and without vegetation and number of breeding pairs at those habitats; $\mathrm{L}=$ colony location (island or mainland); $\mathrm{N}=$ nesting substrate composition; $\mathrm{S}=$ island size, distance to mainland, and area covered by each habitat type; $\mathrm{V}=\mathrm{vegetation}$ cover in plots within the colony; $\mathrm{Vo}=$ vegetation cover in random plots at areas not used by Kelp Gulls; $\mathrm{Vr}=$ vegetation cover in random plots at the breeding location.

c Other species: MP = Magellanic Penguin, GP = Southern Giant Petrel, IC = Imperial Cormorant, RS = Rock Shag, NC = Neotropic Cormorant, GC = Guanay Cormorant, DG = Dolphin Gull, OG = Olrog's Gull, ST = South American Tern, RT = Royal Tern, CT = Cayenne Tern, S= Antarctic or Chilean Skua, $\mathrm{O}=$ South American sea lion, $\mathrm{A}=$ South American fur seal. 